\title{
Cuando traducir conduce al encuentro
}

\section{Heidrun Adler}

El tema remite directamente a una realidad que rebasa el sentido metafórico del traductor como intermediario entre dos idiomas, entre dos literaturas. Pues la traducción de obras de teatro no concluye en el escritorio. Requiere siempre también al escenario, es decir, al actor y la dirección. El contacto ideal entre autor y lector, intermediado por el traductor, deviene aquí en encuentro concreto entre autor y actor/dirección antes de que se pueda dar paso al encuentro abstracto entre autor y público. Suena banal, pero es el quid de aquello que distingue básicamente la traducción de textos de teatro de la traducción de prosa y lírica.

Escrito está: “En el principio era la Palabra".... Aquí me detengo ya perplejo. ¿Quién me ayuda a proseguir? No puedo en manera alguna dar un valor tan elevado a la palabra; debo traducir esto de otro modo si estoy bien iluminado por el Espíritu... Escrito está: "En el principio era el sentido".... Medita bien la primera línea; que tu pluma no se precipite. ¿Es el pensamiento el que todo lo obra y crea?.... Debiera estar así: "En el principio era la Fuerza"... Pero también esta vez, en tanto que esto consigno por escrito, algo me advierte ya que no me atenga a ello. El Espíritu acude en mi auxilio. De improviso veo la solución, y escribo confiado: "En el principio era la Acción." (Goethe Fausto 141-42)

Las reflexiones de Fausto durante la traducción del primer renglón del evangelio de San Juan, en la que por la noción griega de logos traduce sucesivamente Wort, Sinn, Kraft y Tat (palabra, sentido, fuerza y acción), no sólo plantean paradigmáticamente las dificultades de cualquier tarea de traducción. Señalan además las posibilidades hermenéuticas de una traducción. Goethe ofrece aquí una reflexión sobre teoria de la traducción - Wort (palabra) 
y Sinn (sentido) responden al método clásico de una traslación literal, la primera, o acorde al sentido, la segunda.

A su vez, Kraft (fuerza) podría representar (parece anticiparse a) la teoría de la comunicación lingüística (moderna), que sitúa en primer plano la relación entre emisor y receptor, o sea, no propone [representa] una traducción literal ni según el sentido sino una equivalencia del efecto del texto en el lector/oyente. Finalmente, la traducción de logos por Tat (acción) podría sugerir (representar) una teoría pragmática del lenguaje que abarque un contexto aún más amplio en el que cada acto lingüístico - o sea, también la traducción - es una acción (Costazza 87-169). Ninguna de las numerosas investigaciones polémicas de nuestra época sobre la posibilidad o imposibilidad de traducir un texto literario, que culminan en la exigencia de "reproducción del contenido intelectual" (Koschmieder 48-59) o de "reproducción de la experiencia cognitiva" (Jakobson 232ff.), de "transformación del texto por un maestro del arte de traducir" (Gadamer 184-98) o de una "traducción radical" (Quine 27-50), son tan útiles al traductor de teatro como los versos de Goethe. Muestran a través del ejemplo mencionado ambos polos de fidelidad a la obra y libertad de traducción (Eco), donde se subraya la intraducibilidad de determinados conceptos, imágenes o matices que van más allá de la referencia directa, y se demuestran las posibilidades de explotar los diversos usos y acepciones de las palabras.

\section{EI lenguaje hablado es dinámico}

El diálogo teatral no guarda una relación funcional sólo con el habla del lector sino también con los actores sobre el escenario, el público y el personaje que declama. Por tanto, quien traduce literatura teatral no puede proceder como si se tratara de un diálogo novelesco. El diálogo teatral no es ninguna secuencia lingüística cerrada en sí misma; constituye más bien un sistema dinámico a partir del cual, junto con los demás factores de la representación escénica (actores, escenario) se desarrolla la interacción dramática entre los personajes. De ahí que el modus operandi del traductor con un texto de teatro no pueda consistir en la sustitución de un estilo temporal por otro.

El traductor ha de abordar el texto extranjero con un instrumental metódico variable. Ora es más importante matizar el sentido, ora el estilo y la entonación. Determinadas unidades léxicas del diálogo brindan al traductor la información necesaria para interpretar a un personaje. La manera de hablar caracteriza al personaje y motiva sus actos más allá (no sólo dentro) del 
contexto semántico, pues el lenguaje oral es dinámico. Al emplear determinada sintaxis, determinados giros y vocablos, frases largas o cortas, una gramática correcta o incorrecta, el actor desarrolla el gestus que hace visibles tanto cualidades del personaje como de su entorno social.

Las acotaciones del autor pueden fijar la escenografía, el vestuario de los personajes y determinados movimientos sobre el escenario. Aparte de la acción, la idiosincrasia del personaje sólo es reconocible a través de su lenguaje, de lo que dice y, sobre todo, de cómo lo dice. Aquí el traductor puede decidir con su labor si una obra funciona o no. Cualquier traducción errónea de un texto en prosa es reconocida como "desafortunada" y le granjea al autor una cierta compasión. Un texto de teatro que no deja cobrar vida a los personajes, condena a muerte a la obra.

La caracterización parece relativamente sencilla allí donde el habla del personaje se apoya directamente en un determinado registro lingüístico: lenguaje culto o popular, bíblico, epocal, etc. En La noche de Hernán Cortés, Vicente Leñero distingue entre habla popular actual y habla culta con el fin de delimitar distintos planos temporales. Y para citas históricas ficticias recurre a un lenguaje escrito arcaizante.

CORTÉs: Nos fue de la chingada.

Obien:

CORTÉs: Pensé que haber trabajado en la juventud me aprovechara para que en la vejez tuviera descanso, y así ha cuarenta años que me he ocupado en no dormir, mal comer traer las armas acuestas, poner la persona en peligro.... (34)

CORTÉs: (recordando) ...ni desobediencia a su capitán. No hay volver la cara al enemigo que no parezca huida; no hay huida, o si lo queréis colorar, retirada, que no causa a quien la hace infinitos males.... (44) El constante cambio de planos lingüísticos tiene una función dramática. Se quiere presentar a Cortés como un personaje de nuestro tiempo que se traslada al pasado en sueños y recuerdos. Mientras hurga en su memoria, van surgiendo las apariciones. Los únicos personajes auténticos son Cortés y el secretario, que escribe en una computadora la historia de México. Leñero se vale de los mismos recursos en sus otras obras. Anacronismos como la computadora o cigarrillos y mechero en El martirio de Morelos, cuya acción se desarrolla en la época de las guerras de independencia, cumplen la misma función que el uso de diferentes planos lingüísticos: ayudan a producir una impresión de simultaneidad. Leñero nos sugiere que este hombre no es sólo 
un personaje histórico. Es también un individuo actual. La situación descrita se inserta simultáneamente en el pasado y el presente.

Estamos más habituados a que la elección de un determinado registro lingüístico caracterice a un personaje. Con ello el traductor decide acerca del personaje. Por regla no todas las partes de un papel dramático revisten la misma importancia. A veces las primeras réplicas plantean y resuelven el problema de la caracterización del personaje. De ahí que sean de suma importancia para el traductor, ya que transmiten al espectador una imagen de la personalidad que más tarde apenas admite corrección. Por ejemplo, el secretario de Cortés dice:

SeCRETARIO: ¿Nos fue de maravillas señor?

Aquí se ofrecen varias posibilidades de traducción. A mí me pareció decisivo el "nos." Que este "nos" ligeramente irónico implica tanto servilismo como tutelaje (las enfermeras son las únicas que usan la primera persona del plural al dirigirse a otros) queda demostrado cuando en el curso de la acción se va haciendo evidente que en este secretario coexisten varias personas: el secretario histórico de Cortés, López de Gómara, el cronista Bernal Díaz del Castillo, quien narró la historia de la conquista de México y Sancho Panza. El secretario encarna además al político por antonomasia, con su servilismo, falsedad, cinismo y oportunismo, con su hipocresía y adulonería. Todas estas cualidades son subrayadas irónicamente por el hecho de que a veces Cortés le llame Pancho, forma abreviada de Francisco. Así llaman en México a los sirvientes y chóferes de políticos. Todo esto tiene que haberlo tenido presente el actor de acá para que en las primeras réplicas el personaje no apareciera ante el público alemán como una caricatura.

\section{Traducir de las variantes latinoamericanas del castellano}

Los personajes de la literatura teatral latinoamericana se caracterizan por todo un complejo de rasgos idiomáticos de origen social y nacional con los que los europeos no estamos en modo alguno familiarizados. Singulares procesos históricos y estructuras sociales de los distintos países han acuñado formas de conducta que no son directamente transferibles a nuestro contexto social. Los autores latinoamericanos suelen recurrir a arcaísmos para caracterizar un entorno provincial, pero igual lo hacen para señalar niveles jerárquicos. Leñero pone en boca de una criada antiguos giros castellanos como "vide" por "vi," "truje" por "traje" o "ansina" por "así." El mexicano sabe enseguida que esta mujer proviene de la provincia y que jamás en su 
vida fue a la escuela. Una traducción de semejantes giros al alemán plantea dificultades.

Puesto que en gran parte reconocemos el entorno social e intelectual de una persona por su lenguaje, estos y muchos otros giros idiomáticos sin equivalentes léxicos exactos en la lengua de llegada fuerzan al traductor a alejarse del original. Ante tales casos, Karl Kraus recomienda en un juego de palabras nicht übersetzen, no traducir, sino más bien üb-ersezten, "estudia a sustituir."

Por si fuera poco, los latinoamericanos usan un lenguaje corporal diferente al de nosotros los europeos del norte. Hablan con mucha más mímica; mueven la cabeza, las manos, el cuerpo entero. Para poder entender esa amplia paleta de formas expresivas nos es preciso convivir con ellos durante un tiempo. Hay textos del teatro latinoamericano cuyo sentido con frecuencia sólo se nos revela a través del lenguaje corporal de los personajes, es decir, viéndolos y oyéndolos. El efecto conseguido en el original por medio del tono de voz, un determinado patrón melódico, sílabas o vocales dejadas de pronunciar, consonantes aspiradas, gangosidades, el traductor ha de tratar de traducirlo en buena medida por medio de la elección de las palabras y de desviaciones gramaticales de la norma. Esta plétora de rasgos acústicos, aparejada a elementos mímicos, sitúan a los personajes en sus respectivos entornos sociales y no son visibles en el texto impreso.

Un texto de teatro es una obra de arte inacabada que alcanza su acabado final en el escenario. La palabra requiere aún ser puesta en escena, incorporada a un gestus. El traductor también entra armónicamente en este proceso, dice Héctor Azar en una charla en Frankfurt 1993. Una traducción adecuada debería ante todo facilitar la inserción del texto en el gestus de la lengua de llegada. La tarea del actor alemán consiste en declamar un texto que, dentro de su gestus idiomático habitual, expresa aquello que el autor quiso expresar en el original.

¿Debería, pues, ocurrírsenos la idea de producir traducciones de obras de teatro como sincronizaciones filmicas de la puesta en escena original después de la grabación en vídeo? Por diferentes motivos, eso no funciona. La puesta en escena de una obra de teatro nunca es válida para todas épocas. El teatro está mucho más cerca de su público que el cine del suyo. Una obra de teatro admite siempre nuevas puestas en escena. En esto lo decisivo no es que los personajes se asemejen a los del elenco original sino que el gestus idiomático sea entendido por el público. 
Existen incontables casos de piezas que han seguido siendo igualmente grandiosas en sus distintas puestas en escena. Un ejemplo del teatro latinoamericano es el drama Apareceu a Margarida, de Roberto Atayde. La obra, que escenifica el monólogo de una maestra frente a una clase escolar, fue presentada en un festival de teatro celebrado en Kansas en dos versiones: una puesta en escena de Bogotá y otra de Nueva York. Eran dos puestas en escena diferentes ante un público de similar composición: norteamericanos y sudamericanos aproximadamente a partes iguales, más algunos europeos intercalados. Durante la función colombiana reinó un silencio profundo, tenso. Incluso después se habló poco de la obra. La versión neoyorquina contó con una animada participación del público, que en efecto se comportó como un grupo escolar. Las dos versiones lograron transmitir - siempre de una manera distinta pero totalmente adecuada - el terror autoritario, encarnado en esta obra por el personaje de la maestra. ¿Qué significa eso? Las traducciones les habían brindado a las actrices la posibilidad de transferir el texto al gestus de sus respectivos idiomas. El autor estaba presente y se sintió igualmente entusiasmado por las distintas versiones.

Esta confrontación desató durante el festival un largo y provechoso debate sobre la traducción de obras de teatro. El debate culminó en la tesis escueta, provocadora, que sustentan las reflexiones fáusticas citadas al inicio: una traducción puede/debe alejarse ampliamente del original a fin de dar con la versión correcta.

Otro ejemplo de ello es el encuentro en Hamburgo entre original y traducción de la obra Contienda humana de Juan Radrigán. Al respecto escribió la crítica ateniéndose al sentido: "lo que los chilenos llevaron a la escena como fiesta de locos ha devenido pieza de salón en la versión alemana." Tal juicio en modo alguno descalifica la puesta en escena alemana. Más bien dice que el crítico esperaba una sincronización, un espectáculo exótico en idioma alemán. En lugar de eso, se le presentó en el escenario, traducido al gestus de Europa septentrional, el mensaje de la obra: ansiedad, espanto, autodestrucción del individuo bajo un régimen aniquilador de seres humanos. No estaba claro para él que los alemanes reaccionamos en forma introvertida allí donde los latinoamericanos lo hacen en forma extrovertida, que nos mostramos reservados e incisivos allí donde los chilenos pueden mostrarse vehementes y bulliciosos. Pero toda la disparidad de semejantes formas de conducta contradictorias se pone de manifiesto cuando traductor y director/ actores trabajan en colaboración. Por lo demás, la versión alemana de Contienda humana fue acogida por el público tal como el autor lo había 
previsto: provocó ansiedad. La pregunta decisiva, inmanente al texto, planteada por el autor: ¿Cómo te comportarías tú ante esa situación?, había afectado al espectador. En cambio, la apasionada puesta en escena chilena fue objeto de una animada discusión política. Si el grupo teatral alemán hubiese intentado presentarse a la chilena, el drama habría degenerado en farsa. Aquí las expectativas y prejuicios desempeñaron un gran papel, en el cual no profundizaremos ahora por tratarse de factores variables irrelevantes para la supervivencia literaria de una obra. Lo importante es que en ambas piezas, la de Atayde y la de Radrigán, las puestas en escena han destacado la ejemplaridad del texto. Han eliminado lo exótico sin despojar a la obra de su origen.

\section{Traducir y adaptar}

El traductor se mueve siempre entre dos extremos: por un lado, debe reproducir el texto del modo más exacto posible; por el otro, tener presente que ese texto debe ser declamado por actores estranjeros, visto del texto original, y poder ser soportado por aquel público estranjero al contexto de la obra. Los personajes han de cobrar vida en el nuevo idioma en el mismo sentido en que fueron diseñados por el autor. A veces esto no se logra sin considerables intervenciones del traductor en el texto. En la traducción literal suele esfumarse el encanto de la obra. Se comprueba que en otro idioma pasajes enteros provocarían carcajadas no deseadas, que falsean por completo el espíritu de la obra.

No obstante, la cuestión de si se le concede licencia al traductor para adaptar un texto a fin de hacerlo más comprensible al público desata siempre fuertes controversias. Estimamos que, en la práctica, la autoridad del autor, ya sea con respecto al original o a su traducción, cesa en el instante en que el director inicia su labor. Ninguna traducción puede reproducir jamás el original a la perfección. Pero igual cualquier puesta en escena muestra sólo cómo la dirección y los actores son capaces de entender el texto y realizarlo. En este sentido, las querellas teóricas acerca de la imposibilidad de traducir se revelan como fantasmagorías.

Tanto traducción como puesta escena - la última con ayuda de la primera - deben tratar de captar la intención del autor. Deben tratar de acercarse a él lo más posible. Ahora bien, una adaptación del texto no debe ser efectuada en ningún caso por el traductor solo. Más bien el traductor debería atenerse al texto y, en colaboración con el teatro (dramaturgia/actores), 
crear una versión adecuada que, pese a todos los esfuerzos por llegar al público local, mantenga la distancia sociológica y cultural.

Quien busca por sí solo una comprensión cabal del texto, corre siempre el riesgo de proyectar su propio bagaje conceptual sobre el texto, privándolo así de toda posibilidad de ser realmente entendido. Las traducciones no deberían ocultar la distancia con respecto al original sino más bien realzarla. Ciertamente, cuando lo foráneo resulta incomprensible, no se mantiene el tinte extranjero reclamado por el barón Wilhelm von Humboldt. Esa cualidad se revela más bien en la desigualdad con que se expone y resuelve un conflicto comprensible para el público. Goethe opina que, al traducir, hay que "acercarse a lo intraducible, pues sólo entonces se perciben la nación extranjera y el idioma extranjero" (Noten 554).

\section{Alemania}

\section{Obras citadas}

Costazza, Alessandro. Linguistische und hermeneutische Aspekte der Übersetzung, Trento, 1993: 87-169.

Eco, Umberto. Semiotica e filosofia del linguaggio. Turin, 1984.

Gadamer, Gans Georg. Sprache und Verstehen. Hermeneutik II. Tübingen, 1970: 18498.

Goethe, Johann Wolfgang von. Fausto. Traducción de José Roviralta. Buenos Aires: Ediciones Cátedra, 1977: 141-42.

. Noten und Abhandlungen zum besseren Verständnis des Westöstlichen Divans, in Gedenkausgabe Bd. 3. Zürich, 1949: 554.

Jakobson, Roman: On Linguistic Aspects of Translation. Brower, Reuben Arthur: On Translation. Cambridge, 1959: $232 \mathrm{ff}$.

Koschmieder, Erich. Das Problem des Übersetzens. Darmstadt, 1981: 48-59.

Leñero, Vicente. La noche de Hernán Cortés. México, 1992.

Quine, Willard van. Zwei Dogmen des Empirismus. Von einem logischen Standpunkt. Frankfurt/Wien/Berlin, 1979:27-50. 